\title{
Possible Growth Retrieval Simulation on the Heat-Stressed Pseudomonas aeruginosa (SUBP01) Cells
}

\author{
M Sakil Munna, Kazi Rumana Tanzim, M Mohibul Hassan Afrad, Sanjida Humayun, M Sidiqur Rahman, Mahbuba \\ Akter Lubna and Rashed Noor* \\ Department of Microbiology, Stamford University Bangladesh, 51 Siddeswari Road, Dhaka 1217, Bangladesh
}

\begin{abstract}
Earlier observation of cellular damage of Pseudomonas aeruginosa (SUBP01) by the extrinsic oxidative agent $\left(\mathrm{H}_{2} \mathrm{O}_{2}\right)$ and the assumptive accumulation of the reactive oxygen species (ROS) through aeration further led to the growth retrieval assay of the bacterium. Current study investigated the influence of the inorganic growth stabilizers (20 mM MgSO $\mathrm{m}_{4}$ plus $5 \mathrm{mM}$ ethylenediaminetetraacetic acid, EDTA) and the organic extracellular fractions of the heat-resistant Bacillus species (SUBB01) and P. fluorescens (SUBP02) on the growth pattern of $P$. aeruginosa at $45^{\circ}$ and $46^{\circ} \mathrm{C}$. Bacterial growth (cfu) was measured on the minimal agar plates up to 72 hours, microscopic experiments to monitor the subsequent morphological changes, and finally by the spot tests to examine the cell viability under the given heat stressed conditions. As expected, growth revival was observed at both $45^{\circ}$ and $46^{\circ} \mathrm{C}$ after 48 to 72 hours, upon supplementation with inorganic growth stabilizing agents and the extracellular fractions (secretions) of $P$. fluorescens compared to that of the control; i.e., untreated with inorganic or organic supplements. Interestingly, compared to that of $P$. fluorescens extracellular extracts, no positive impact on growth retrieval was noticed by the application of the extracellular fractions of Bacillus species.
\end{abstract}

Keywords: Bacillus spp. (SUBB01), Pseudomonas aeruginosa (SUBP01), P. fluorescens (SUBP02), Heat-stress, Growth retrieval

\section{Introduction}

Pseudomonas species are common Gram-negative, rod-shaped bacteria prevailing the environment, where they may undergo unfavourable environmental circumstances including heat shock, oxidative stress, nutrient depletion, divergence within the optimal $\mathrm{pH}$, restricted water activity $\left(\mathrm{a}_{\mathrm{w}}\right)$, osmotic imbalance, etc. ${ }^{1-5}$. In response to such stress signals, an array of molecular chaperones, principally CspB and CspE in Bacillus spp., GroEL and DnaK proteins in Salmonella spp., RpoE, RpoS and RpoH proteins in Escherichia coli and Pseudomonas spp., has been reported to be expressed ${ }^{6-19}$. While such chaperone mediated defense mechanisms may vary along different bacterial cells. Interestingly, a remarkably strong defense strategy has been noticed in Bacillus spp. and Pseudomonas fluorescens ${ }^{12-13,20-21}$. The heat shock stimulon of Bacillus spp. is the most complicated ever described in bacteria, encoding around 200 heat shock genes, regulated by at least 6 different mechanisms depending on species ${ }^{20-24}$. Notably, $P$. fluorescens revealed the frequent occurrence of extracytoplasmic function (ECF) sigma (ó) factors, which serve as important regulatory defensive agents in response to the stress signals including the elevated temperature, irradiation, alteration in $\mathrm{pH}$ and the redox state, reactive oxygen species (ROS), toxic compounds, and nutrient depletions ${ }^{1-5,17,25-27}$.
In our earlier studies, the cellular impact in response to the external and internal oxidative stresses ${ }^{16-17,25-27}$ and heat shock (unpublished) in E. coli, Pseudomonas spp., Bacillus spp. and Salmonella spp. has been inquired well and evidently brought the new information on the defense strategy within Bacillus spp. and Salmonella spp. as observed through their sustainability in producing the colony forming units (CFUs). Under high aeration speed at 200 rotations per minute (rpm), with a concomitant elevation of internal oxidative stress, E. coli and Pseudomonas cells were found to loss viability, while Bacillus spp. remained uninfluenced ${ }^{26}$. Notably, a heterogeneous population was observed within the Pseudomonas spp. whereby a few unstressed cells evolved, which were later identified as $P$. fluorescence cells leaving the $P$. aeruginosa fractions as stressed cells ${ }^{26}$. In another study, supplementation of the hydrogen peroxide $\left(\mathrm{H}_{2} \mathrm{O}_{2}\right.$, an external oxidant) was found to retard the growth of $E$. coli and Pseudomonas spp., whereas Bacillus spp. were found to be unaffected ${ }^{27}$. Such findings were quite interesting especially regarding Pseudomonas spp. since lots of stress related investigations have been chalked out within E. coli cells.

Based on such rationale on the identification of the heat resistant Bacillus and P. fluorescence cells, current study further endeavoured to scrutinize whether the supplementation of the

*Corresponding author:

Rashed Noor, Department of Microbiology, Stamford University Bangladesh, 51 Siddeswari Road, Dhaka 1217, Bangladesh

Tel: +880 (02) 8355626,E-mail: noor.rashed@yahoo.com 
extracellular growth enhancing factors of Bacillus spp. (SUBB01) or $P$. fluorescence (SUBP02) in the medium fraction could retrieve the growth of heat stressed $P$. aeruginosa cells (SUBP01), grown at high temperatures up to $46^{\circ} \mathrm{C}$. Moreover, earlier studies reported that $\mathrm{Mg}^{2+}$ (in the form of $\mathrm{MgSO}_{4}$ ) and ethylenediamine tetraacetic acid (EDTA) were capable to protect the outer membrane from the incidence of cell burst within $E$. coli upon heat shock as well as to protect the subsequent damage imposed on proteins and DNA $^{19,28-29}$. Thus, besides the impact of organic supplements, the effect of the inorganic growth stabilizing agents $\left(\mathrm{MgSO}_{4}\right.$ and EDTA) was also investigated to bring about the comparative effects on bacterial cellular growth retrieval.

\section{Methods and Materials}

Bacterial stain, medium, and culture conditions

Laboratory stock cultures of Bacillus spp. (SUBB01), Pseudomonas aeruginosa (SUBP01) and P. fluorescens (SUBP02) were used in this study. Experiments demonstrating the bacterial growth in terms of cell turbidity (optical density at $600 \mathrm{~nm}, \mathrm{OD}_{600}$ ) and colony forming units (cfu) were conducted as described earlier ${ }^{27}$. Minimal agar and broth (Sigma-Aldrich, USA) were used for the assessment of culturability ${ }^{7}$. After 24 hour incubation on nutrient agar plates at $37^{\circ} \mathrm{C}$, one loopful of the bacterial culture was introduced into $5 \mathrm{ml}$ nutrient broth followed by incubation at $37^{\circ} \mathrm{C}$ for 4-6 hours at $100 \mathrm{rpm}$ (pre-culture). After adjusting optical density of the pre-culture at $600 \mathrm{~nm}\left(\mathrm{OD}_{600}\right)$ to $0.1,30 \mu \mathrm{l}$ each was introduced into 3 different sets of minimal agar broth $(30 \mathrm{ml})$ and incubated at $45^{\circ}$ and $46^{\circ} \mathrm{C}$. At every 12 hours interval, the cell growth was monitored by measuring $\mathrm{OD}_{600}$ and by counting the colony forming units (cfu) up to 72 hours $^{7,25-27}$. Revelation of culturable cells was further confirmed by the supportive spot tests $^{7,25-27}$. As described previously, each the culture suspension was serially diluted in $9 \mathrm{ml}$ nutrient broth to obtain up to $10^{-4}$ fold dilution ${ }^{27}$. From each dilution, an aliquot of $5 \mu$ l was dropped on to the minimal agar, dried off for 15 minutes, and finally the plates were incubated at $37^{\circ} \mathrm{C}$ for 24 hours.

\section{Demonstration of morphological changes}

Simple staining (crystal violet, Hucker's solution) was conducted to assess the viability and the cellular morphology as described previously ${ }^{25-27}$. An aliquot of $10 \mu$ from the bacterial culture suspension was removed at 24 hours of growth, and the cellular morphology, shape and organization were observed under the light microscope (Optima Biological Microscope G206, Taiwan) at $1,000 x$ magnification ${ }^{25-27}$.

\section{Preparation of organic and inorganic supplements}

To prepare the extracellular fractions of bacteria (Bacillus sp. and $P$. fluorescens), cells were grown separately into 6 different sets of Durham's bottle containing $5 \mathrm{ml}$ minimal broth, which were kept in shaking water bath at $100 \mathrm{rpm}$ for 24 hours at $37^{\circ} \mathrm{C}$. Subsequently, actively growing bacterial cells were centrifuged at 4,000 rpm for 15 minutes, and the resulting pellets were collected. Afterward pellets were centrifuged at 4,000 rpm for 15 minutes for 3 times with $10 \%$ glycerol and $50 \mathrm{mM} \mathrm{CaCl}$ respectively ${ }^{30}$. The resulting supernatants were collected and used as organic supplement to observe the possible retrieval of $P$. aeruginosa cell viability both at $45^{\circ}$ and $46^{\circ} \mathrm{C}$. Subsequently, a mixture of $20 \mathrm{mM} \mathrm{MgSO}_{4}$ and $5 \mathrm{mM}$ EDTA were used as inorganic supplement to conduct the similar experiment ${ }^{19}$.

\section{Results and Discussions}

Revolution of growth and viability of Pseudomonas aeruginosa As stated above, our previous studies investigated the strong defense strategies of Bacillus sp. SUBB0127 and Pseudomonas fluorescens (unpublished) in response to the oxidative stress artificially created by the supplementation of $\mathrm{H}_{2} \mathrm{O}_{2}$ into the growing culture. Notably, at the early stationary phase, E. coli undergoes lysis mechanism appears to remove VBNC (viable but nonculturable) cells accumulated at the transition period from exponential to stationary phases ${ }^{16,31}$. Moreover, heterogeneity in $E$. coli population was reported before it entered stasis ${ }^{16,32}$, where $E$. coli were assumed to uptake the probable stress resistance factors and possibly balance the viable and culturable cell population (Figure 1). Based on this suggestive idea, present study designed an ingenious simulation model of growth retrieval, and employed a possible positive defensive strategy on the heat stressed $P$. aeruginosa growth at $45^{\circ}$ and $46^{\circ} \mathrm{C}$ temperature by means of supplementation of the (1) extracellular (secreted into the culture media) fractions of P. fluorescens and of (2) Bacillus

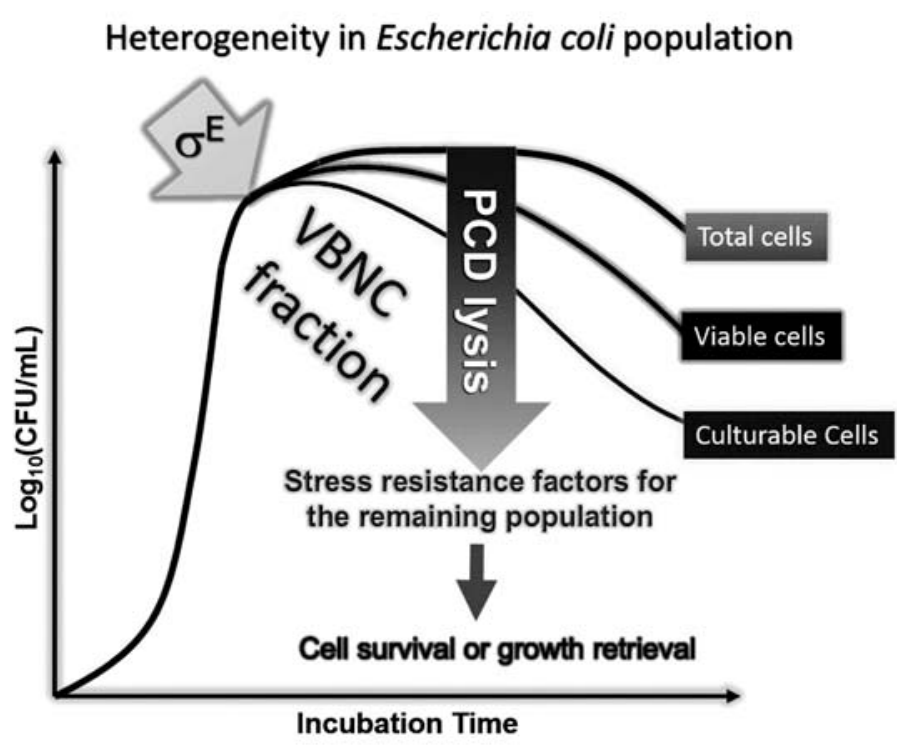

Figure 1. Possible Growth revival strategies of stressed Escherichia coli cells $7,16-17,31$. The heat stressed cells of E. coli were assumed to be fractionated into the viable cells, viable but non-culturable (VBNC) cells and dead cells in the early stationary phase. The surviving viable and culturable cell fractions are thought to uptake the debris generated from the lysis dead cells and the VBNC cells triggered by $s^{E}$ regulon gene transcription and translation. 
species as organic supplement which was further compared to that of (3) the inorganic supplement ( $\mathrm{Mg}^{2+}$ with EDTA) into the culture media of heat stressed $P$. aeruginosa (Figure 2).
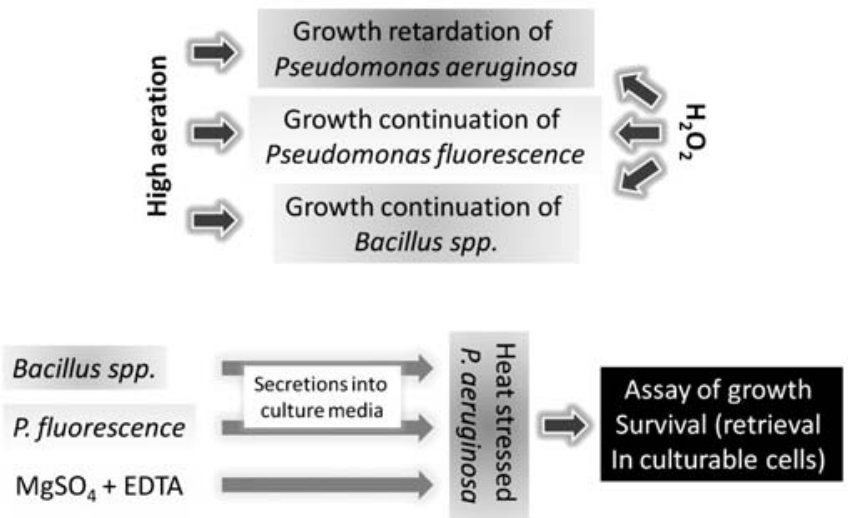

Figure 2. Rationale and objectives of the current study. Previously data has shown that high aeration at 200 rpm and the addition of $\mathrm{H}_{2} \mathrm{O}_{2}$ caused the loss of culturability of Pseudomonas aeruginosa while Bacillus spp. and $P$. fluorescence were found to be comparatively resistant against such stresses ${ }^{26-27}$. Based on these findings, current study endeavored to examine whether the supplementation of the extracellular factors of Bacillus spp. (SUBB01) or P. fluorescence (SUBP02) in the medium fraction could retrieve the growth of heat stressed P. aeruginosa cells (SUBP01), grown at $45^{\circ} \mathrm{C}$ and $46^{\circ} \mathrm{C}$. Effect of the inorganic growth stabilizing agents $\left(\mathrm{MgSO}_{4}\right.$ and EDTA) was also investigated.

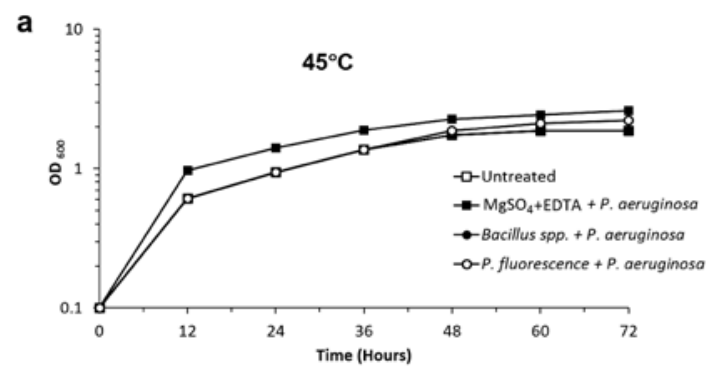

C

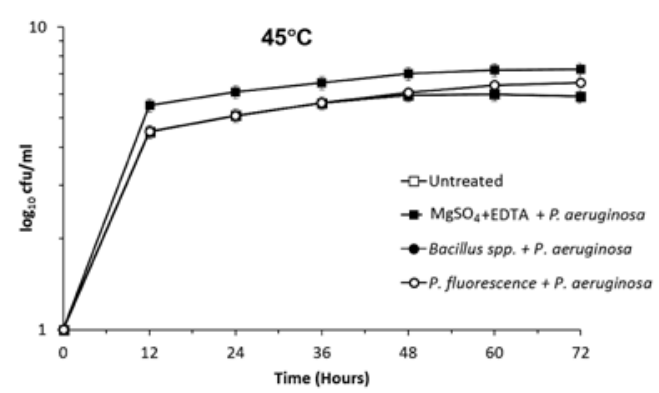

In this study, when $P$. aeruginosa cells were grown with the extracellular fractions of $P$. fluorescens at $45^{\circ}$ and $46^{\circ} \mathrm{C}$, a growth revival was observed in cell turbidity (Figure $3 \mathrm{a}, \mathrm{b}, \mathrm{c}$ and d) as well as in the generation of cfus compared to that of the control; i.e., untreated and the cells treated with $20 \mathrm{mMMgSO}_{4}$ with $5 \mathrm{mM}$ EDTA. Besides, no significant changes were observed when cells were grown with the extracellular fractions of Bacillus species (Figure 3). In consistent to the results obtained from the growth related experiments, no morphological change was observed under light microscope $(1,000 x)$, when cells were subjected to grown with the extracellular fractions of Bacillus species compared to those treated with $20 \mathrm{mM} \mathrm{MgSO}_{4}$ with $5 \mathrm{mM}$ EDTA, untreated (control). Notably, an increase in the number was observed when cells were grown with the extracellular fractions of $P$. fluorescens at $45^{\circ}$ and $46^{\circ} \mathrm{C}$ (Figure 4 ).

Confirmative demonstration of growth retrieval of P. aeruginosa cells

As stated earlier, after 48 hours of incubation, $P$. aeruginosa cells were surprisingly found to retrieve their cell turbidity at $600 \mathrm{~nm}$ along with the generation of the culturable cells at $45^{\circ}$ and $46^{\circ} \mathrm{C}$ upon supplementation with the extracellular fractions of $P$. fluorescens and inorganic supplement compared to the control and those grown with the extracellular fractions of Bacillus species led us to further cross-check of the growth retrieval trait of the cells through the spot tests as stated earlier ${ }^{25-27}$. Consistent
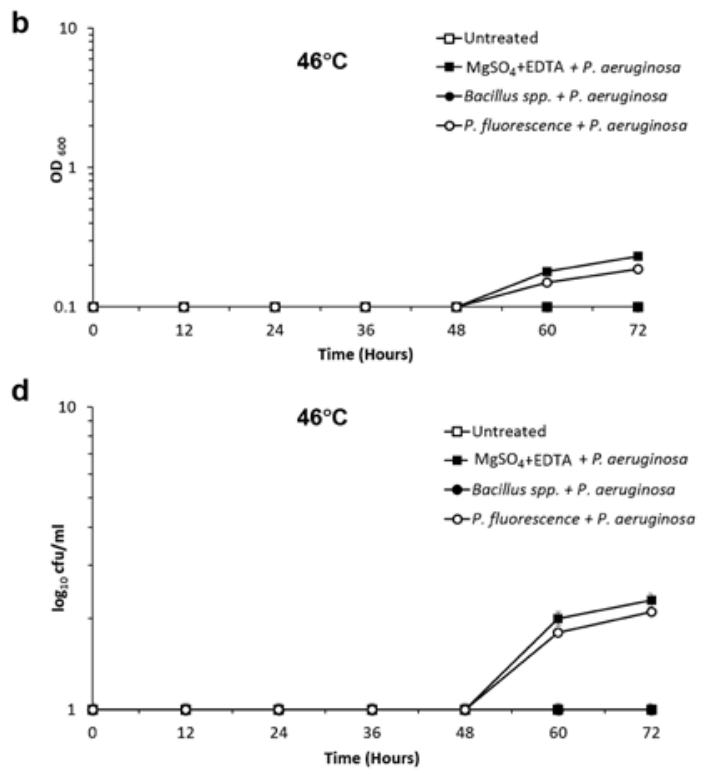

Figure 3. Growth revival of Pseudomonas aeruginosa (SUBP01) in terms of cell turbidity ( $a$, $b$ ) and colony forming units (c, d) at $45^{\circ} \mathrm{C}(\mathrm{a}, \mathrm{c})$ and $46^{\circ} \mathrm{C}(\mathrm{b}, \mathrm{d})$, upon supplementation with $\mathrm{MgSO}_{4}$, and EDTA as inorganic supplement and the extracellular fractions of Bacillus species (SUBB01) and Pseudomonas ûuorescens (SUBP02) as organic supplement. The experiment carried out through the examination of cell turbidity by measuring $\mathrm{OD}_{600}$. P. aeruginosa (SUBP01) were grown in minimal media at $45^{\circ}$ and $46^{\circ} \mathrm{C}$ and after 10 hours of growth $20 \mathrm{mM} \mathrm{MgSO}_{4}$ with $5 \mathrm{mM} \mathrm{EDTA}$, the extracellular fractions of Bacillus species (SUBB01) and P. ûuorescens (SUBP02) were added seperatly. A growth revival was observed at both $45^{\circ} \mathrm{C}(\mathrm{a}, \mathrm{c})$ and $46^{\circ} \mathrm{C}(\mathrm{b}, \mathrm{d})$, grown with $20 \mathrm{mM} \mathrm{MgSO}{ }_{4}$ with $5 \mathrm{mM}$ EDTA and extracellular fractions of P. ûuorescens (SUBP02) compared to that of the control; i.e., untreated, and the cells treated with extracellular fractions of Bacillus species (SUBB01). 


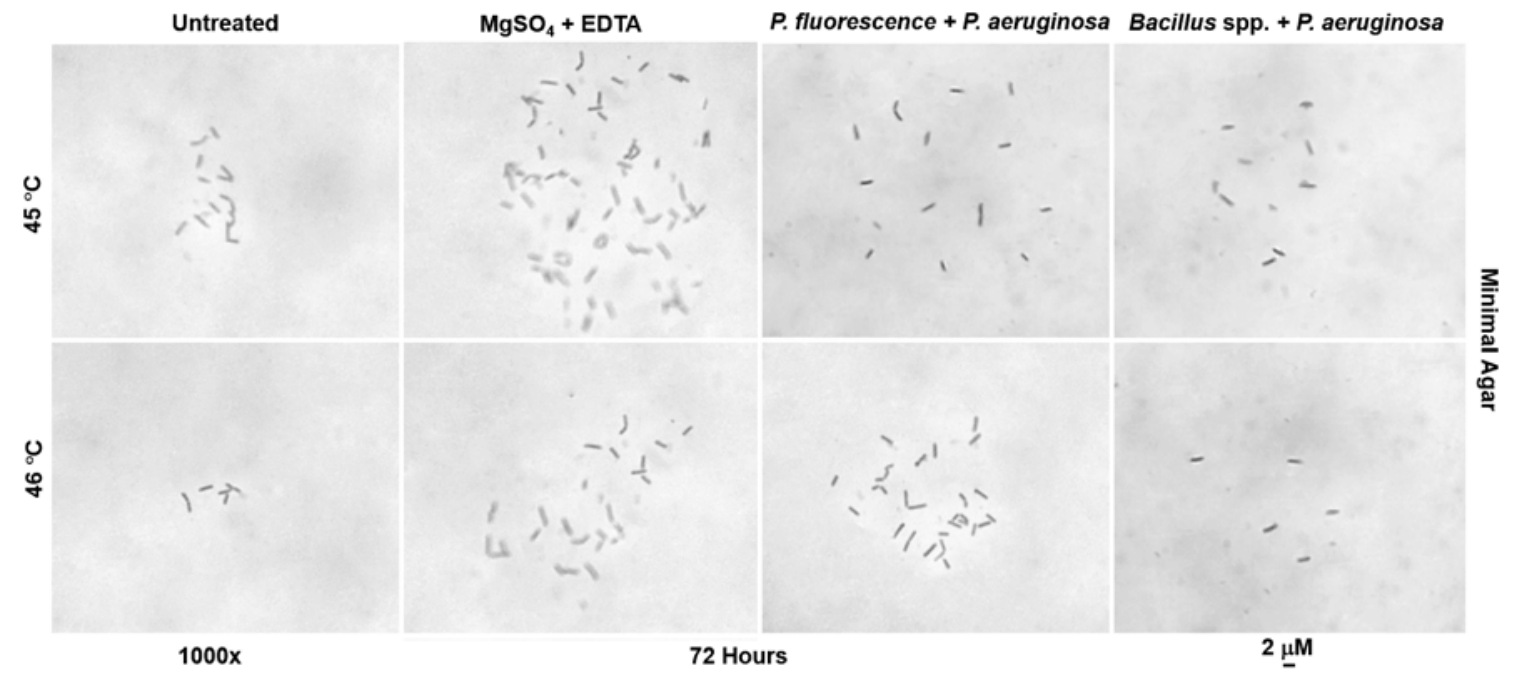

Figure 4. Morphological impairment of Pseudomonas aeruginosa (SUBP01) at $45^{\circ}$ and $46^{\circ} \mathrm{C}$. However, morphologically recovered cells were observed after 72 hours of incubation periods when cells were grown with the extracellular fractions $P$. ûuorescens (SUBP02). Notably, no cells were observed at both $45^{\circ}$ and $46^{\circ} \mathrm{C}$, upon supplementation with the extracellular fractions of Bacillus species (SUBB01).

to the growth experiments as shown in figure 1 and figure 2, a growth revival of $P$. aeruginosa cells was observed at $45^{\circ}$ and $56^{\circ} \mathrm{C}$ upon supplementation with the extracellular fractions of $P$. fluorescens with minimal variation with the cells treated with 20 $\mathrm{mM} \mathrm{MgSO}_{4}$ with $5 \mathrm{mM}$ EDTA in minimal agar (Figure 5). No significant changes were observed when cells were grown with the extracellular fractions of Bacillus species.

Earlier studies revealed that $E$. coli cells exhibited $\mathrm{s}^{\mathrm{E}}$ dependent cell lysis at early stationary phase, which might be one type of programmed cell death (PCD) $)^{15,17,32}$. Several studies showed that various physiological and morphological changes during the early stationary phase appears to be similar in Escherichia coli and Pseudomonas spp. ${ }^{12-13,33}$. Considering the idea of nutrient support by cell lysis and the organism might make some kind of equilibrium in cell population, the current study also proposed a model based on the present findings (Figure 6). The model evidently figures out the possible positive effect on the heat stressed $P$. aeruginosa (SUBP01) growth at high temperature upon the supplementation of the extracellular fractions of $P$. fluorescens (SUBP02) as organic growth supplement.

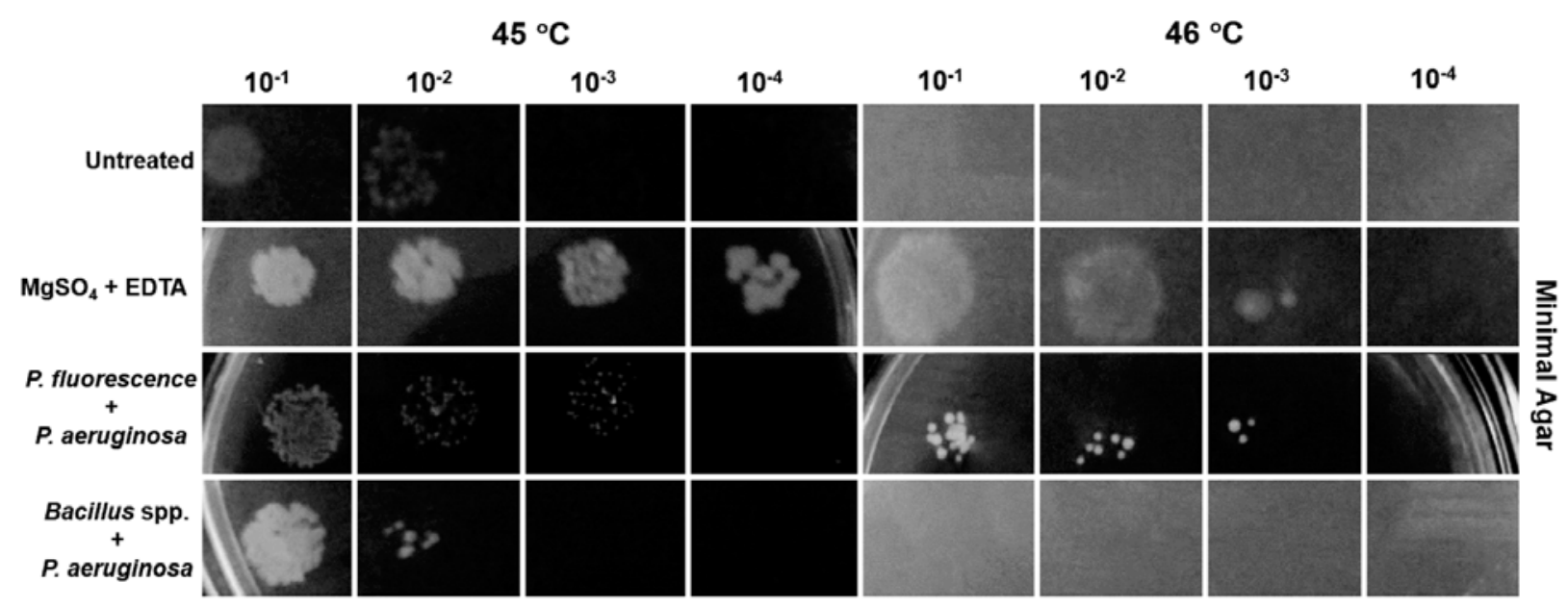

72 Hours

Figure 5. Revolution of cell viability and culturability of Pseudomonas aeruginosa (SUBP01) in minimal agar (MA). In the MA agar, a steady growth was found at both $45^{\circ}$ and $46^{\circ} \mathrm{C}$ after 72 hours of incubation periods upon supplementation with the extracellular fractions P. ûuorescens (SUBP02) compared to that of the control; i.e., untreated and the cells treated with extracellular fractions of Bacillus species (SUBB01). 


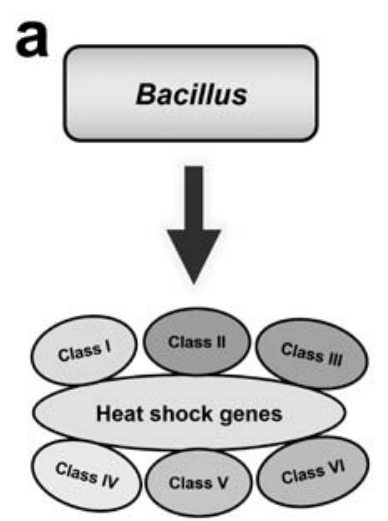

\section{Accumulation of Stress Resistance factors}
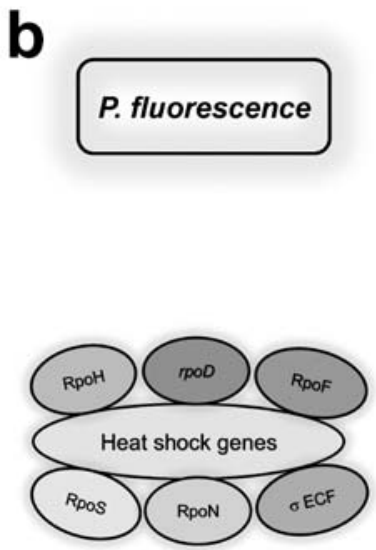

Accumulation of Stress Resistance factors

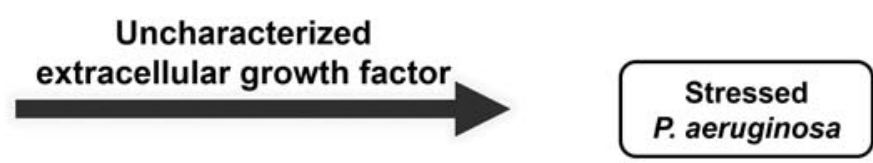

Viable but non-culturable state

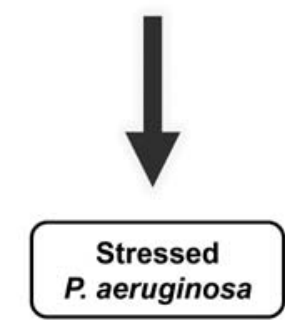

Still non-culturable

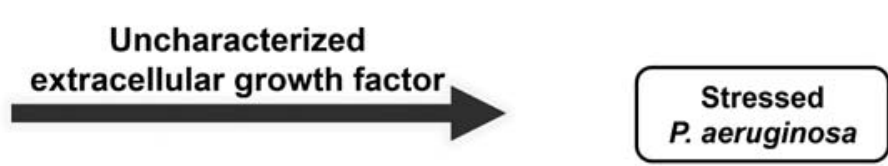

Viable but non-culturable state

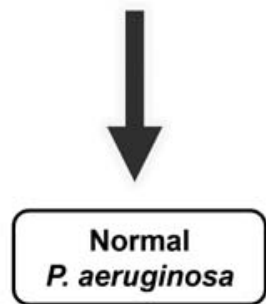

Culturable state on solid media

Figure 6. The model of the growth retrieval of Pseudomonas aeruginosa (SUBP01). Notably, no significant changes were observed, when cells were grown with the extracellular fractions of Bacillus species (SUBB01) compared to those treated with the extracellular fractions of P. ûuorescens (SUBP02).

\section{Conclusion}

Our previous study has demonstrated that E. coli and $P$. aeruginosa lose its culturability upon oxidative stress, where Bacillus spp. and P. fluorescens revealed an eliciting different cellular stress response mechanism. The current investigation further uravalled the revolution of growth and viability of $P$. aeruginosa at high temperature and co-metabolic relationship between P. aeruginosa, P. fluorescens and Bacillus species. Despite the lack of genetic investigation, current study has sufficiently exhibited the positive impact of bacterial extracellular extracts on growth resuscitation, which so far has been evident for the first time in case of Pseudomonas spp. Further studies at the genetic level would unveil the molecular mechanism underlying the reasons of growth retrieval of $P$. aeruginosa by $P$. fluorescence but not by Bacillus spp.

\section{References}

1. Rungrassamee W, Ryan KC, Maroney MJ and Pomposiello PJ. 2009. The PqrR transcriptional repressor of Pseudomonas aeruginosa transduces redox signals via an iron-containing prosthetic group. $J$ Bacteriol. 191: 6709-6721.

2. Rungrassamee W. 2008. Oxidative Stress Responses in Escherichia coli and Pseudomonas aeruginosa. University of Massachusetts Amherst, Amherst, Massachusetts.

3. Sabra K, Kim EJ and Zeng AP. 2002. Physiological response of Pseudomonas aeruginosa PAO1 to oxidative stress in controlled microaerobic and aerobic cultures. Microbiology. 148: 3195-3202.

4. Moat AG, Foster JW and Spector MP. 2002. Lipids and sterols. In Microbial Physiology, $4^{\text {th }}$ edn, pp 450-464. John Wiley and Sons Inc, New York.

5. Givskov M, Eberl L, Moller S, Poulsen LK and Molin S. 1994. Responses to nutrient starvation in Pseudomonas putida KT2442: Analysis of general cross-protection, cell shape, and macromolecular content. J Bacteriol. 176: 7-14.

6. Den Besten HMW, Effraimidou S and Abee T. 2013. Catalase activity as a biomarker for mild stress-induced robustness in Bacillus weihenstephanensis. Appl Environ Microb. 79: 57-62.

7. Noor R, Islam Z, Munshi SK and Rahman F. 2013. Influence of temperature on Escherichia coli growth in different culture media. $J$ Pure Appl Microbiol. 7(2): 899-904. 
8. Tang SW, Abubakar S, Devi S, Puthucheary S and Pang T. 1997. Induction and characterization of heat shock proteins of Salmonella typhi and their reactivity with sera from patients with typhoid fever. Infect Immun. 65(7): 2983-2986.

9. Ramos-Gonzalez MI and Molin S. 1998. Cloning, sequencing, and phenotypic characterization of the rpoS gene from Pseudomonas putida KT2440. J Bacteriol. 180: 3421-3431.

10. Miller CD, Mortensen WS, Braga GUL and Anderson AJ. 2001. The rpoS gene in Pseudomonas syringae is important in surviving exposure to the near-UV in sunlight. Curr Microbiol. 43: 374-377.

11. Periago PM, Schaik WV, Abee T and Wouters JA. 2002. Identification of proteins involved in the heat stress response of Bacillus cereus ATCC 14579. Appl Environ Microbiol. 68(7): 3486-3495.

12. Stockwell VO and Loper JE. 2005. The sigma factor RpoS is required for stress tolerance and environmental ûtness of Pseudomonas ûuorescens Pf-5. Microbiology. 151: 3001-3009.

13. Heeb S, Valverde C, Gigot-Bonnefoy C and Haas D. 2005. Role of the stress sigma factor RpoS in GacA/RsmA-controlled secondary metabolism and resistance to oxidative stress in Pseudomonas ûuorescens CHA0. FEMS Microbiol Lett. 243: 251-258.

14. Kabir MS, Yamashita D, Noor R and Yamada M. 2004. Effect of $\mathrm{s}^{\mathrm{S}}$ on $\mathrm{s}^{\mathrm{E}}$-directed cell lysis in Escherichia coli early stationary phase. $J$ Mol Microbiol Biotechnol. 8:189-194.

15. Kabir MS, Yamashita D, Koyama S, Oshima T, Kurokawa K, Maeda M, Tsunedomi R, Murata M, Wada C, Mori H and Yamada M. 2005. Cell lysis $\mathrm{s}^{\mathrm{E}}$ in early stationary phase and effect of induction of $\mathrm{s}$ directed by the rpoE gene on global gene expression in Escherichia coli. Microbiology. 151: 2721-2735.

16. Noor R, Murata M and Yamada M. 2009. Oxidative stress as a trigger for growth phase-specific ó ${ }^{\mathrm{E}}$ dependent cell lysis in Escherichia coli. J Mol Microbiol Biotechnol. 17: 177-187.

17. Noor R, Murata M, Nagamitsu H, Klein G, Raina S and Yamada M. 2009. Dissection of ó $^{\mathrm{E}}$ dependent cell lysis in Escherichia coli: roles of RpoE regulators RseA, RseB and periplasmic folding catalyst Ppid. Genes Cells. 14: 885-899.

18. Murata M, Fujimoto H, Nishimura K, Charoensuk K, Nagamitsu H, Raina S, Kosaka T, Oshima T, Ogasawara N and Yamada M. 2011. Molecular strategy for survival at a critical high temperature in Eschierichia coli. PLoS One. 6(6): e20063.

19. Murata M, Noor R, Nagamitsu H, Tanaka S and Yamada M. 2012. Novel pathway directed by $\mathrm{s}^{\mathrm{E}}$ to cause cell lysis in Escherichia coli. Genes Cells. 17: 234-247.
20. Schumann W. 2003. The Bacillus subtilis heatshock stimulon. Cell Stress Chaperone. 8: 207-217.

21. Versteeg S, Escher A, Wende A, Wiegert T and Schumann W. 2003. Regulation of the Bacillus subtilis heat shock gene htpG is under positive control. J Bacteriol. 185(2): 466-474.

22. Bardwell JCA and Craig EA. 1988. Ancient heat shock gene is dispensable. J Bacteriol. 170: 2977-2983.

23. Haldenwang WG. 1995. The sigma factors of Bacillus subtilis. Microbiol Rev. 59: 1-30.

24. Reder A, Gerth U and Hecker M. 2012. Initiation in Bacillus subtilis decision-making process of sporulation. J Bacteriol. 194: 1065-1074.

25. Munna MS, Nur IT, Rahman T and Noor R. 2013. Influence of exogenous oxidative stress on Escherichia coli cell growth, viability and morphology. Am J BioScience. 1(4): 59-62.

26. Munna MS, Tamanna S, Afrin MR, Sharif GA, Mazumder C, Kana KS, Urmi NJ, Uddin MA, Rhaman T and Noor R. 2014. Influence of aeration speed on bacterial colony forming unit (CFU) formation capacity. Am J Microbiol Res. 2(1): 47-51.

27. Nur IT, Munna MS and Noor R. 2014. Study of exogenous oxidative stress response in Escherichia coli, Pseudomonas spp., Bacillus spp. and Salmonella spp. Turk J Biol. 38: 502-509.

28. Kneidinger B, Marolda C, Graninger M, Zamyatina A, McArthur F, Kosma P, Valvano MA and Messner P. 2002. Biosynthesis pathway of ADP-L-glycero-beta-D-manno-heptose in Escherichia coli. J Bacteriol. 184: 363-369.

29. Dominguez K and Ward WS. 2009. A novel nuclease activity that is activated by $\mathrm{Ca}^{(2+)}$ chelated to EGTA. Syst Biol Reprod Med. 55(56): 193-199.

30. Hanahan D. 1983. Studies on transformation of Escherichia coli with plasmids. J Mol Biol. 166: 557-580.

31. Nitta T, Nagamitsu H, Murata M, Izu H and Yamada M. 2000. Function of the ó $^{\mathrm{r}}$ regulon in dead-cell lysis in stationary phase Escherichia coli. J Bacteriol. 182: 5231-5237.

32. Cuny C, Dukan L, Fraysse L, Ballesteros M and Dukan S. 2005. Investigations of the first events leading to the loss of culturability during Escherichia coli starvation: Future nonculturable bacteria form a subpopulation. J Bacteriol. 187: 2244-2248.

33. Venturi V. 2003. Control of rpoS transcription in Escherichia coli and Pseudomonas: why so different? Mol Microbiol. 49(1): 1-9. 